\title{
The politics of public space in the media city
}

\section{Scott McQuire}

\section{Abstract}

What happens when the TV screen leaves home and moves back into the city?

The public domain of the 21st century is no longer defined simply by material structures such as streets and plazas. But nor is it defined solely by the virtual space of electronic media. Rather the public domain now emerges in the complex interaction of material and immaterial spaces. These hybrid spaces may be called 'media cities'. In this essay, I argue that different instances of the public space in modernity have emerged in the shifting nexus between urban structures and specific media forms. Drawing on the pioneering work of sociologist Richard Sennnett, I offer a critical analysis of the forms of access and modes of interaction, which might support a democratic public culture in cities connected by digital networks and illuminated by large urban screens. 


\section{Introduction}

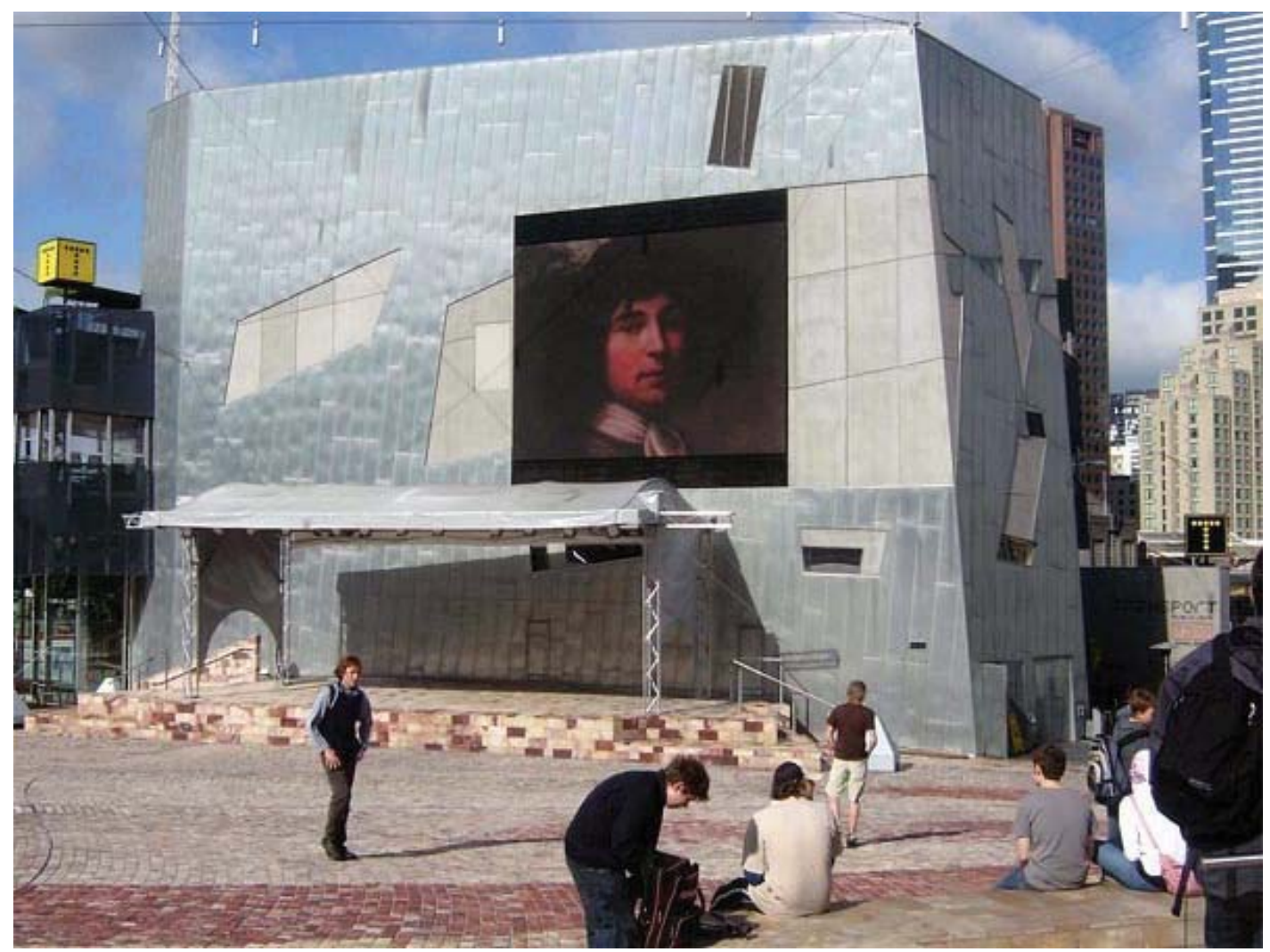

Figure 1: Big Screen, Federation Square, Melbourne. Photograph Meredith Martin

From the initial experiments in cities such as Tokyo and New York, the migration of electronic screens into the external cityscape has become one of the most visible tendencies of contemporary urbanism. The old television set has morphed from a small-scale appliance - a material object, a piece of furniture primarily associated with domestic space - to become an architectural surface resident not in the home but in the street outside. This transformation has intersected the other major transformations of media technology and culture over the last two decades: the formation of distributed global networks which erode regional and national broadcast boundaries, and the emergence of mobile media platforms such as cell phones which displace the architecture which accreted around fixed media. The cumulative impact of these developments on the relation between media space and urban space has been profound. 


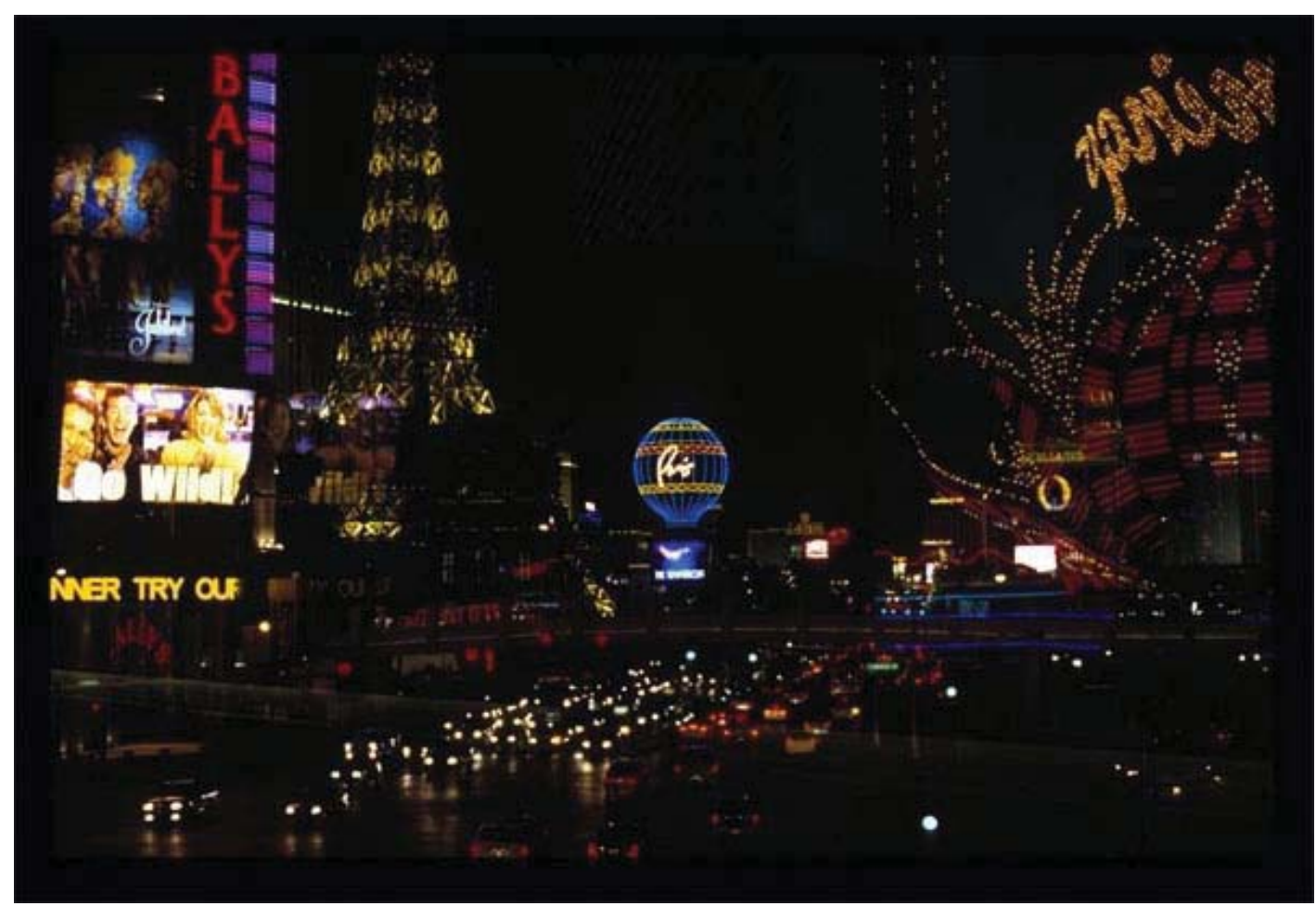

Figure 2: Las Vegas Boulevard, Las Vegas: sophisticated forms of electric lighting

It has produced prototypes of what Paul Virilio calls the 'media building': a building that houses information rather than habitation. Virilio sets the media building in a lineage with earlier structures such as the medieval cathedral to indicate lines of both continuity and rupture. If both can be said to offer information, they are fundamentally divided by its speed of transmission. Electronic screens do not form part of a building's memory in the way frescoes or stained glass windows could; rather their restless constantly changing imagery contribute to a dematerialization of architecture, a sense of ephemerality which is pervasive in 21 st century urbanism. 


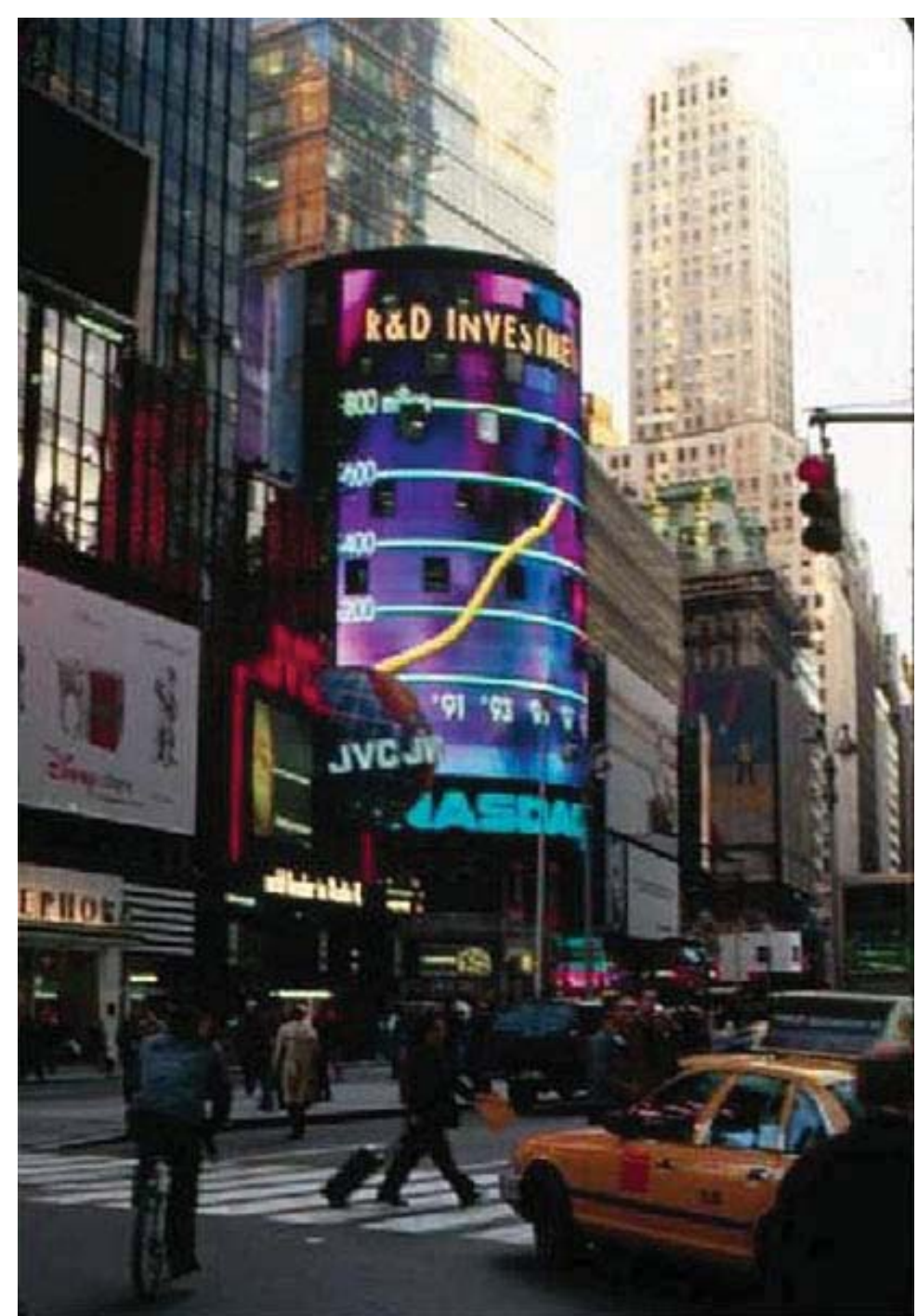

Figure 3: Nasdaq Building, Times Square, Fox and Fowle with its nearly 19 million LEDs

While public screens were initially startling in their novelty, this has waned as large screens with better colour resolution became cheaper to install and operate. In a move which could be compared with the rush in the 1920 s to create 'Great White Ways' to rival the electric lights of Manhattan's Broadway, cities across the world turned en masse to large-scale screens as a popular strategy for 'reinvigorating' public space in the 1990s.

\section{Decline of public culture, demise of public space}

How should we understand these new forms of public spectating? What impact do they have on public space, or on the media's role as a public sphere in Habermas' sense? The decline of public culture, and the related demise of public space became a familiar tale in the late 20 th century. Influential analysts such as Habermas (1989), Jane Jacobs (1961) Richard Sennett (1977), Marshall Berman (1982), and David Harvey (2003) all argued that the public culture which had characterised an earlier modernism had been displaced by a pervasive withdrawal into a private sphere.

In architectural terms, the rise of the suburbs was positioned as the nemesis to the public space of the modern city. The integration of suburban life with 
national broadcast systems after WWII meant that electronic media such as radio and television subsumed more and more of the roles once reserved for public space. In this vein, Daniel Dayan and Elihu Katz (1992) defined the 'media event' largely in terms of the privatization of the public sphere: events once experienced collectively in public space were increasingly consumed by greater numbers of people who watched from the privacy of their individual homes.

Virilio's (1994: 64) account of the displacement of traditional public spaces such as city squares, plazas, streets and boulevards by 'public image' in The Vision Machine sketches a similar trajectory:

This public image has today replaced the former public spaces in which social communication took place. Avenues and public venues are from now on eclipsed by the screen, by electronic displays, in preview of the 'vision machines' just around the corner. [...] Really once public space yields to public image, surveillance and street lighting can be expected to shift too, from the street to the domestic display terminal.

In his book Complexity and Contradiction in Architecture (published in 1966 and one of the key texts of architectural postmodernism), Robert Venturi put a more positive spin on the transformation, famously polemicising against older forms of public space: 'The piazza, in fact, is "un-American." Americans feel uncomfortable sitting in a square: they should be working at the office or home with the family looking at television'.

It is this trajectory leading inexorably from public to private that is now being confused by new generations of media technologies. With the emergence of mobile devices, media consumption is increasingly occurring in public. It could be argued that the 'media event' is in the process of returning to the public domain. But what is the significance of this return? What impact will the electronic screen have on the dynamics of the street, the self-proclaimed birthplace of modernism?

If the space of the city has historically been defined by the relation between (relatively) static structures and mobile subjects, this dichotomy is giving way to hybrid spatialities characterised by dynamic flows which not only dissolve the fixity of traditional modes of spatial enclosure, but problematic the unified presence of the subject traversing their contours.

To better understand the contemporary interplay between media and public space, I want to briefly trace the trajectory, which took modern culture from the street to the screen and then back again. Arguments for and against 'the street' not only register tensions in competing visions of the modern city as the site of a cosmopolitan public culture; they serve as an important framework for understanding the psychogeographical function of electronic media as the hinge between public and private life in modernity.

These arguments also index the crucial political dimension to debates over media culture and public space. The history of screen technologies in modernity, particularly the way they have been integrated into the spatial dynamics of the modern city, has been dominated by the production of new forms of spectacle on the one hand, and new forms of urban policing and surveillance on the other. To what extent can new media technologies they be used to promote other forms of spatial agency? The interesting thing about large screens is that, unlike cell phones or MP3 players which tend towards individual forms of consumption 'mobile privatization' to adapt Raymond Williams' phrase - they are oriented towards collective forms of engagement. It is the nature of that engagement which interests me. 


\section{The media city}

Part of the argument I want to put forward is that each instantiation of urban public space in modernity has been articulated with specific media platforms. This is why I use the term the 'media city' rather than the better-known descriptors such as the 'information city'. The justification is beyond the scope of this paper, but briefly: I think it is important to recognize a longer and more diverse history of the mediated production of urban space than the tight concentration on ICTs by those such as Castells. The visual and the audio-visual have become increasingly important to contemporary spatial experience; ICTs have converged with older media industries to produce image and soundscapes, which are integral dimensions of the 21st century city. Finally, since my focus is more on changes in the lived experience of urban space rather than economic effects; in this sense it is more useful to think of 'media' as an environment in McLuhan's sense;

The modern city has become a media-architecture complex in which the mediatised production of urban space has become a constitutive frame for a new mode of social experience. It's an experience characterized by what I call relational space: space which has been stripped of inherent qualities, such as stable dimensions and appearances (and of course stable social meanings), but is increasingly experienced as shifting, variable and contingent. Relational space can only be defined by the temporary position occupied by each subject in relation to numerous others, which suggests that relational space is not easily unified since every subject belongs to multiple matrices or networks that overlap and interpenetrate. The heterogeneity of relational space is a key experience of contemporary globalization, and demands new ways of thinking about how we might share space to constitute collective experience.

Large screens are a distinctive recent element of the media city, but I think the process has been going on for a long time: at least 150 years. What I want to do here is briefly trace 4 moments or snapshots in this development, as a way of thinking about public space in the present.

\section{Paris}

Mid-19 th century Paris is often seen as the key site for the emergence of cultural modernity: Walter Benjamin describes it in this vein as Capital of the 19th Century. Partly a result of the political developments of 1789; but also of the profound reshaping of the old medieval city under Haussmann from the 1850 s - a project which was in part directed by a desire to secure the city against the radical working class. The immensity of Haussmann's undertaking is covered extensively in architecture and in social theory [David Harvey, T.J Clarke].

In the new public spaces, a new type of public life emerged - in the cafés and parks, but above all on the boulevards themselves. We see the emergence of the crowd as specific social actor in the modern city. The heterogeneity of the crowd, as described by those such as Poe and Baudelaire, is central to the cultural dynamism of modernity. As Georg Simmel will put it, the characteristic experience of the modern city is living among strangers who remain strangers: in other words, these strangers do not pass through, as they might have in the village, but they stay. But in staying they do not necessarily become familiar.

It is this gathering of strangers, with its tendency to produce unexpected conjunctions, which underlies Richard Sennett's optimistic rationale for modern urban life; he argues that in such a context experience is inevitably subjected to 
multiple collisions or jolts:

'These jolts are necessary to a human being to give him that sense of tentativeness about his own beliefs which every civilized person must have'.

In other words, the structural conditions of modern urban life militate against absolutism and in favour of cosmopolitanism - the cosmopolitan being the 'perfect public man' in Sennett's terms. Like Sennett, Benjamin stresses the ambivalence of the new public spaces; an ambivalence felt most strongly in his analysis of the flâneur: the flâneur has a liminal quality for a time, insofar as flanerie is not yet fully drawn into the commodity culture which was rapidly expanding in the mid-19th century.

What this means is that he flâneur is able - for a brief time - to make visible the politics of the new public spaces before ways of behaving in them have become habitual and sedimented. However, gradually the 'unproductive' practice of flanerie gives way to the 'productive' practice of shopping in the department store - a form of social activity that finds aesthetic pleasure in the new form of commodity display born of mass production of consumer goods.

The department store is symptomatic of the broader transformation of modern urban culture pioneered in Paris - a transformation in which, in Clarke's terms, the city becomes something separate from the people who inhabit it. Instead it increasingly takes on the quality of a panorama, a pantomime, or spectacle in Debord's sense - not just an image, but a specific social form in which social relations are increasingly mediated by images. The corollary of spectacular society is the levelling of social experience. As the market economy extended entered into more areas of social life, experience was increasingly dominated by purely quantitative measurement; by the sense that everything had a price and could therefore be compared on that basis.

It's worth returning here to Sennett'saccount of the decline of public culture. Sennett contends that a new public culture had emerged in the 18th century. His timeframe is similar to Habermas' account of the flowering of the public sphere in the period between the Enlightenment-inspired demise of political absolutism and the rise of commercial media.

For Sennett, this public culture depended on the distance granted by social rules and conventions. It was on this basis that strangers could engage with each other in public: 'Playacting in the form of manners, conventions, and ritual gestures is the very stuff out of which public relations are formed...' (1977: 29). The importance of playacting is that it involves testing out boundaries; it moves social rules from the background of the taken-for-granted into the foreground of public consciousness. Playacting in public can therefore take on political connotations - it can become the basis for a collective reassessment of habit and custom.

However, like Habermas, Sennett argues that the emancipatory moment of public culture was all too brief, and that the balance between private and public behaviour was progressively altered during the 19th century. The new conditions of commodity capitalism and secular belief militated against the forms of social interaction, which were vital to sustaining cosmopolitan public culture. The rise of the commodity creates a countervailing demand for personal intimacy and psychological authenticity. People came to believe 'that community is a mutual act of self-disclosure':

[...] in an age wherein intimate relations determine what shall be believable, conventions, artifices and rules appear only to get in the way of revealing oneself to another; they are obstructions of intimate expression. As the imbalance between public and intimate life has grown greater, people have become less expressive. With an 
emphasis on psychological authenticity, people become inartistic in daily life because they are unable to tap the fundamental creative strength of the actor, the ability to play with and invest feeling in external images of the self. (Sennett 1977: 37)

As a result, Sennett argues that public expression was reduced to a special quality thought to inhere only in certain individuals, such as actors, musicians, artists, and, importantly, politicians. The majority of people, who did not believe themselves to possess these special expressive capacities, instead resorted to defensive mechanisms for appearing in public: silence, uniform dress and behaviour. In this context, a new mode of public behaviour became dominant: There grew up the idea that strangers had no right to speak to each other, that each man possessed as a public right an invisible shield, a right to be left alone. (Sennett 1977: 27)

The result was a public culture privileging looking over talking, detachment over engagement: 'Public behaviour was a matter of observation, of passive participation, of a certain kind of voyeurism'. (1977: 27). Expression, on the other hand, was relegated to the private sphere of family life. Mutual playacting among strangers as the basis for public interaction - interactions which might lead to collective political action - were doubly displaced, firstly by the retreat of authentic personal expression into the sanctuary of the family and, secondly, by heightened reliance on charismatic secular leaders for public expression. This is the point at which politics begins to become image politics in a modern sense.

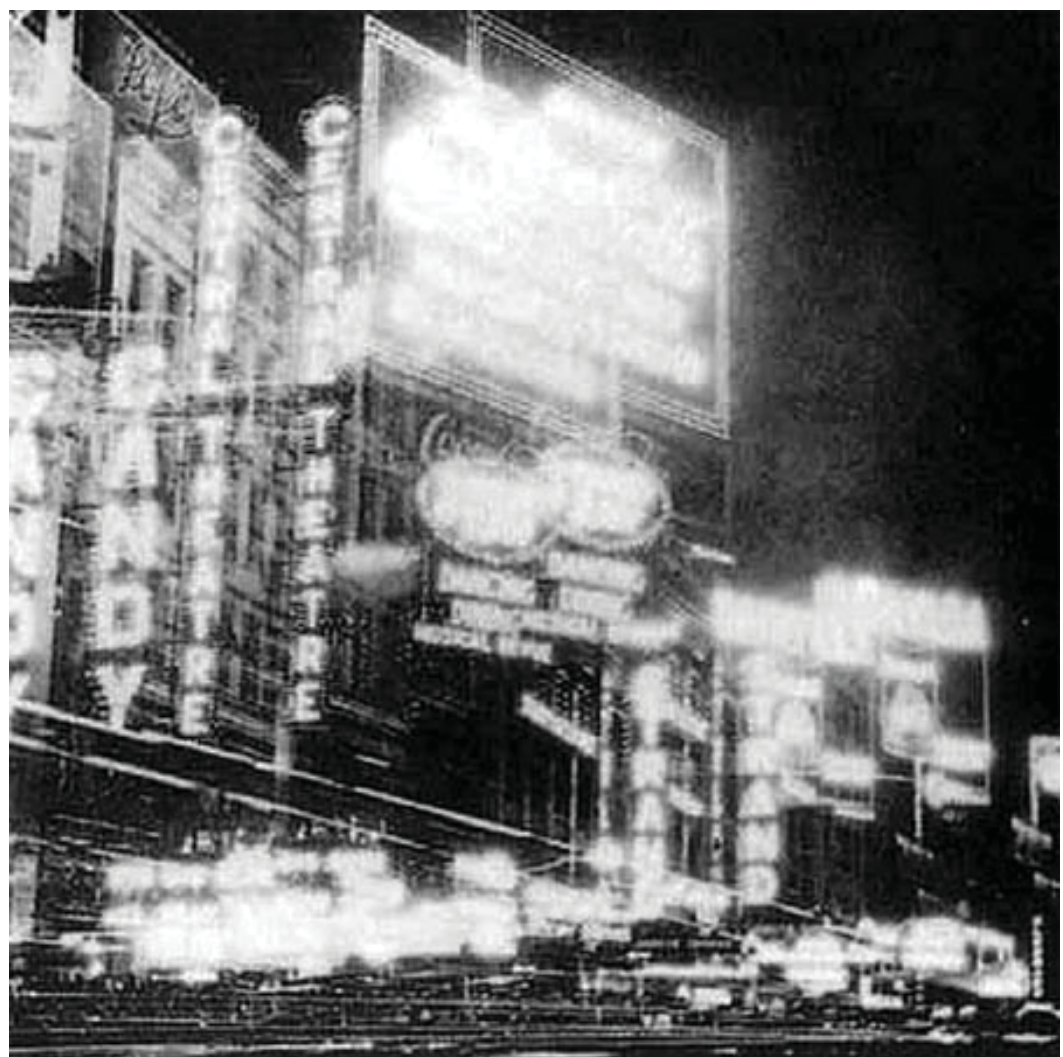

Figure 4: Photograph of Broadway, New York, 1924 Photograph Fritz Lang

\section{Berlin}

This is perhaps a good moment to fast forward to 1920 s Berlin where Benjamin and Kracauer began writing their analyses of 19th century Parisian culture. The crowd has now morphed into the 'masses'. Seen by many, on both Left and 
Right, as a debased form of humanity - debased by mechanization and massproduction, by the transition from rural to urban industrial society, politicisation of the masses is the key political issue of the period, which is dominated by the great class struggle between capitalism and communism.

Germany, not Russia, was the expected site of revolution; following the Kaiser's abdication in the aftermath of World War I the tenuous grip of the Weimar Republic is rocked during the 1920s by a series of attempted coups from both left and right. The street is still a key political site; revolution is a matter of occupying space - the factory, the street, the Winter Palace etc. But already such interactions in public space are overlayed with, if not overshadowed by, interactions in media space.

Urban space in 1920s Berlin was markedly different to 1860s Paris: a mediabased commodity space was more firmly established. One dividing line was electrification: like New York, Berlin was a renowned 'electropolis'. Electric lighting can be understood as a forerunner in some respects to the appearance of large screens in the city: the solidity of buildings - their mass, stable shape, sense of volume - all begin to waver as they are floodlit.

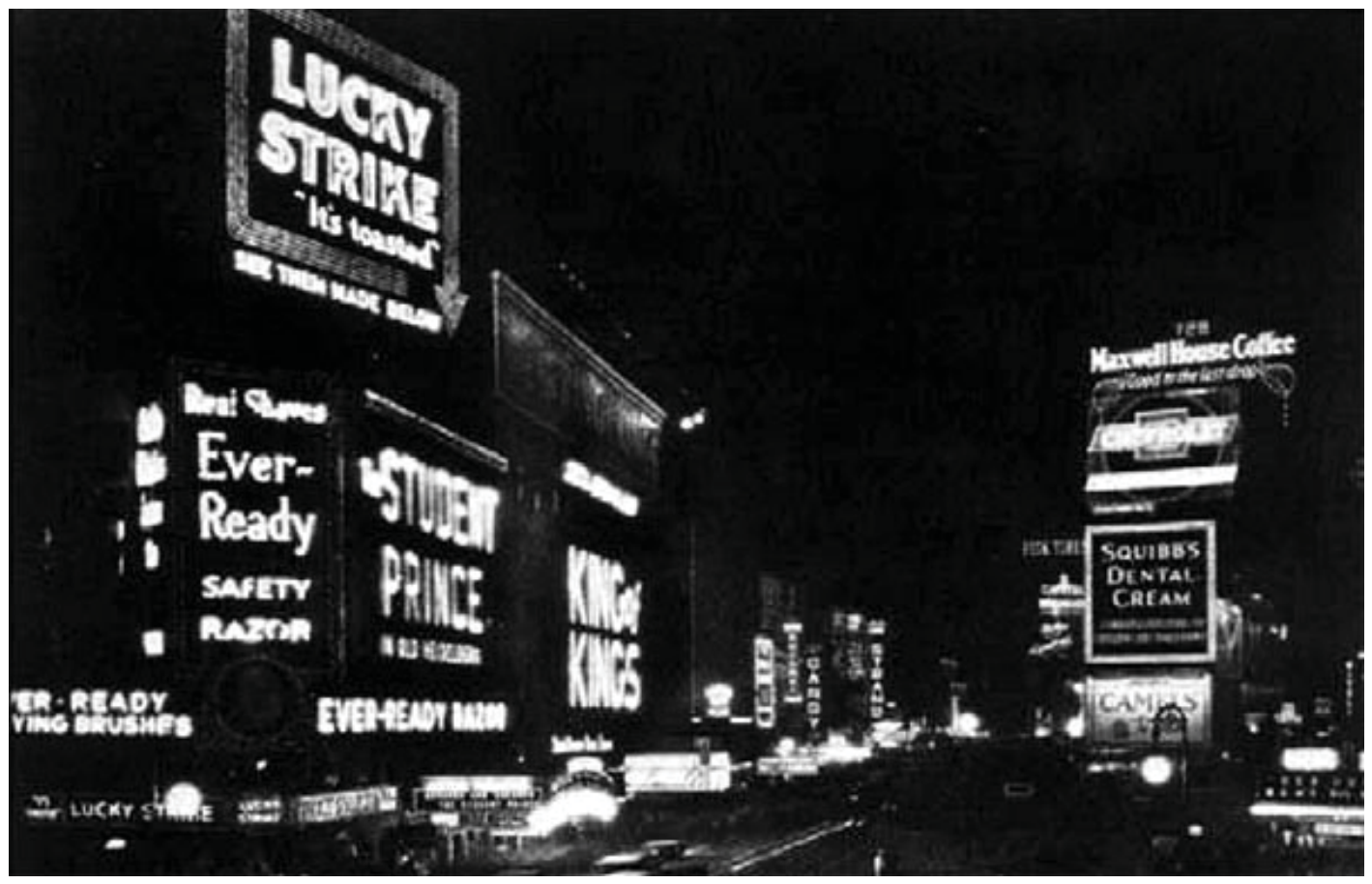

Figure 5: Times Square at night, New York, 1927

Street signage is a distinctive feature of the modern cityscape. While it is a visible symbol of the domination of public space by commodity capitalism literally space become a commodity - it shouldn't be reduced to this. As David Nye points out, despite its rational pretensions, the lighting of the modern city has always been characterized by excess. This probably explains the attitude of the modernist avant-garde to advertising signs, seeing them as an attack on the beaux-arts aesthetic - for example, Léger extolled the way billboard sliced open the visual horizon, while Benjamin clearly locates the electric sign's radical potential in its spatial effect rather than its meagre content: 'What in the end makes advertisements so superior to criticism? Not what the moving red neon sign says ... but the fiery pool reflecting it in the asphalt.' (Benjamin 1996: 476)

While the dazzling environment of the city is still dominated by existing class structures, there is still a level of political ambivalence to spectacular space: a sense that the destabilization of tradition may enable radical political change as a corollary to technological and economic change. One of the distinctive features 
of Benjamin's analyses of the period is his insistence that the technological image is the key to developing new forms of political collectivity. Hence his famous comments in his 'Artwork' essay on the importance of cinema in exploding the 'prison-world' of the modern city with the dynamite of the splitsecond.

However, in retrospect it can more clearly be seen that the 1920 s and 1930 s marked the zenith of a certain idea of public culture and public space: the liminal political space produced by the expansion of capitalism was welded into new unities in which technological media played a key role. On the one hand, the destructive racially based unities of fascism and communism where media such as radio and cinema were used to engineer ecstatic fusion of the masses with the leader. On the other hand, the Fordist mass consumption lifestyle pioneered in the US, where advertising and lifestyle marketing produced a new image politics fusing the star culture of Hollywood with expanded commodity circulation. After the WWII this political settlement fetishising the individual in terms of private rights and consumer choice spread across large swathes of the world. It's in this context that the idea of public culture and urban public space which animated an earlier modernity begins to recede significantly, especially in the US.

\section{Post-urban space/suburbia}

If the 1920s can be seen as the zenith of the modern industrial city, its decline becomes more evident after WWII. In the US, official policies supported suburbanization: subsidised Federal loans for returned soldier housing fuelled the flight from inner city areas which were themselves starved of funds. The scale of transformation was unprecedented: between 1940-47, 60 million Americans nearly half the population-moved to new homes. City centres were increasingly 'black' ghettos contrasted to the new 'white' suburban developments such as Levittown. Suburbs altered the balance between public and private space. As Kasinitz (1994: 275) argues:

Suburbs $[. .$,$] are notably rich in private spaces and poor in public$ ones. By the postwar era even the layout of American homes spacious backyards and 'decks' replacing front porches and stoops had come to express a turning away from the street and towards controllable domesticity.

The desire to turn away from the unpredictability and chaos of the street had, in fact, been a prominent architectural theme from the 1920s - it was central to Le Corbusier's writings, and informed the functional zoning of CIAM's Athens Charter in 1933. One of the central issues was the problem of the car: Le Corbusier rejected public transport in favour of the separation of vehicular and pedestrian traffic. The corridor street is declared obsolete in favour of the arterial road and the internal corridor: 'Most of the city's streets will now be inside the buildings' (1964: 113) - an idea which returns with a vengeance in the 1980s with the proliferation of shopping malls, skyways and pedestrian tunnels.

The connection is the desire for highly controlled forms of public space. What increasingly replaces the public encounters characteristic of older urban form is the electronic media: as Virilio puts it: 'The screen abruptly became the city square'. Suburbanization corresponds to the rise of broadcast TV: in this phase the media displace interactions in public space by constructing alternative means for virtual participation in collective social life: as the home becomes a media centre, social life is increasingly characterised by a retreat to the private. This is the condition for the emergence of a fully-fledged image politics. 
medium. TV brings us close to politicians in a new way - intimacy re-emerges from the bosom of the family to become the dominant model for political life, and arguably for all social relations. In Sennett's terms contemporary public life has come to be increasingly characterised by 'destructive Gemeinschaft', as social relationships are treated as 'disclosures of personality'. Today this is often called the 'character' issue - the tendency to judge politicians and other public figures according to perceptions of their character, what we think they are like 'as a person'.

If Sennett's analysis can undoubtedly be read in terms of his unspoken fear of the 'feminization' of public culture through the generalization of intimacy, it shouldn't be reduced to this. There is also a critical political dimension, which turns on the need to develop forms of public behaviour that do not depend wholly on evaluating the 'authenticity' of the other's character. What's wrong with judging character? Nothing, if you really know someone.

The problem is that modern social encounters, especially those orchestrated through the media, grant limited ability to make such judgements. Yet the nature of contemporary political debate means that such judgements are routinely demanded. The result is a raging trade in manufactured tokens of intimacy and personal authenticity in a variety of forms ranging from political advertising and brand promotion to confessional media and reality television. This reduction of politics to image is symptomatic of the broader reduction of public culture to spectacle - not something you contribute to, but something that you generally consume.

\section{The post-broadcast digital era}

So how might this change as we move into a post-broadcast digital era, and we see the re-emergence of the screen into public space? The demise of public space was probably always overstated, but this is becoming clearer as media technologies become ubiquitous, mobile and scalable, and are commonly embedded in urban infrastructure or carried in the course of daily life.

Historically, large screens have primarily been used in 2 ways: as relays for live events: (rock concerts, sports) or to provide flexible platforms for information \& advertising. These uses largely comply with spectacular public space, with the appropriation of the city as spectacle, but there is also a history of alternative content: e.g. the text based installations by Jenny Holzer in the mid-80s. 


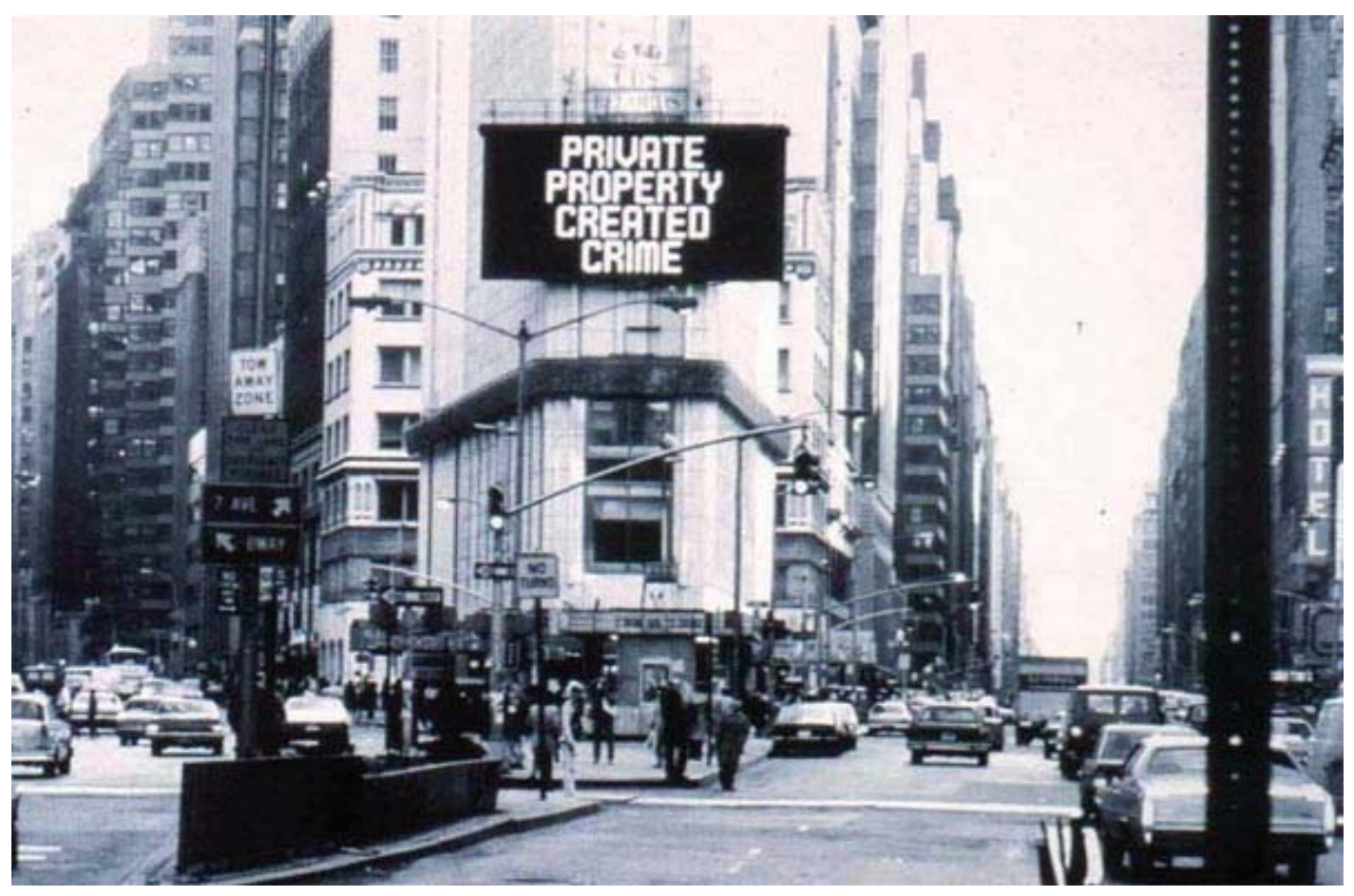

Figure 6: Jenny Holzer, 'Private Property Created Crime', 1985. Times Square, New York

Holzer's work suggests that a key issue for large screens in public space remains the traditional issue for all media forms: control, access, filtering of content etc. But there's also another way of thinking about potential use. If we take up Sennett's metaphor of play - not necessarily in the way he intended it - we also need to imagine uses of screens which don't simply to produce alternative content, but are directed to producing new forms of public relationships.

\section{Andreas Broeckmann (2000) has argued:}

The challenge to the creative use of media technologies is fostering the diversity of public actors and terrains and to develop strategies of articulating the new public domains that connect physical urban spaces and the potential public sphere of the electronic networks. This public sphere will only come into being if there are complex forms of interaction, of participation and learning, that use the technical possibilities of the new networks and that allow for new and creative forms of becoming visible, becoming present, becoming active, in short, of becoming public.

More than a decade ago David Rokeby argued that digital aesthetics is about creating relationships rather than finished art works; more recently Nicholas Bourriaud has talked about this in terms of 'relational aesthetics', where the aim of the work of art is not the construction of an object or image, but of social relationships. Social relationships of whatever kind are not natural - they need to be learned, nurtured and practiced. New forms of public interaction which involve sharing and negotiation between individual and collective agency can play a vital role in challenging the dominance of public space by spectacular 'brandscapes' or its pacification by surveillance. 


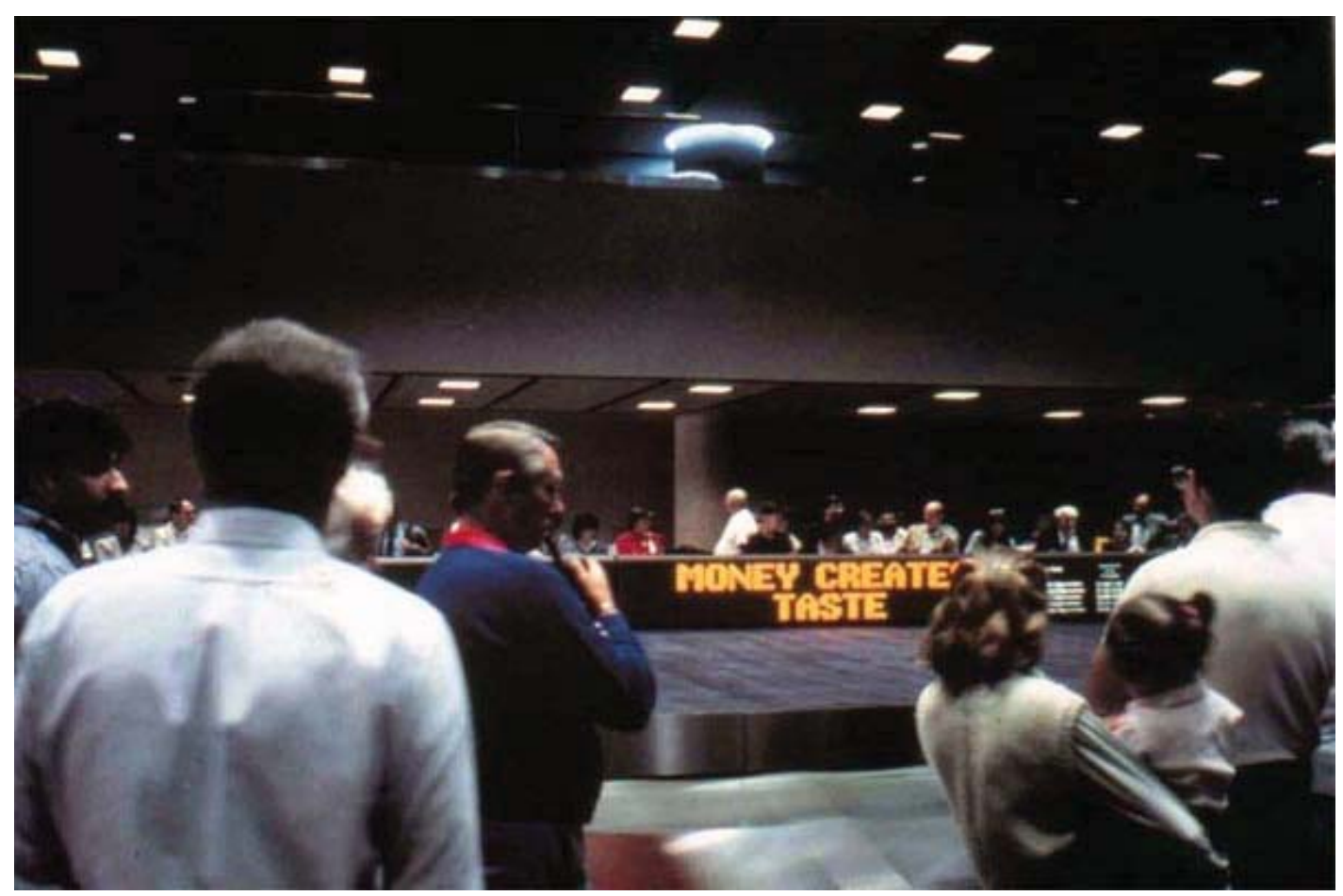

Figure 7: Jenny Holzer 'Money Creates Taste', 1986. LED display, McCarran Airport, Las Vegas

This is where I find Rafael Lozano-Hemmer's 'relational aesthetics' projects particularly interesting. Body Movies first staged in Rotterdam in 2001: not a large screen, but a large-scale projection piece which I think offers an interesting model for developing a public culture comprising interactive media in public space. It's a work which emphasises public participation - 'interactivity' is not simply a choice among a menu of predictable consequences, but belongs to a more open horizon in which contingency and unpredictability play a greater role. Instead of the logic of 'taking turns', where single users produce representations that others can see, up to fifty people could participate in Body Movies together. This interface created a delicate balance between personal participation and collective interaction, between active engagement and reflective contemplation. But the most striking aspect of Body Movies was the playful engagement it sustained among groups of erstwhile strangers who came together in public space, and discovered that by enacting a collective choreography, they could affect the visual ambiance of public space. 


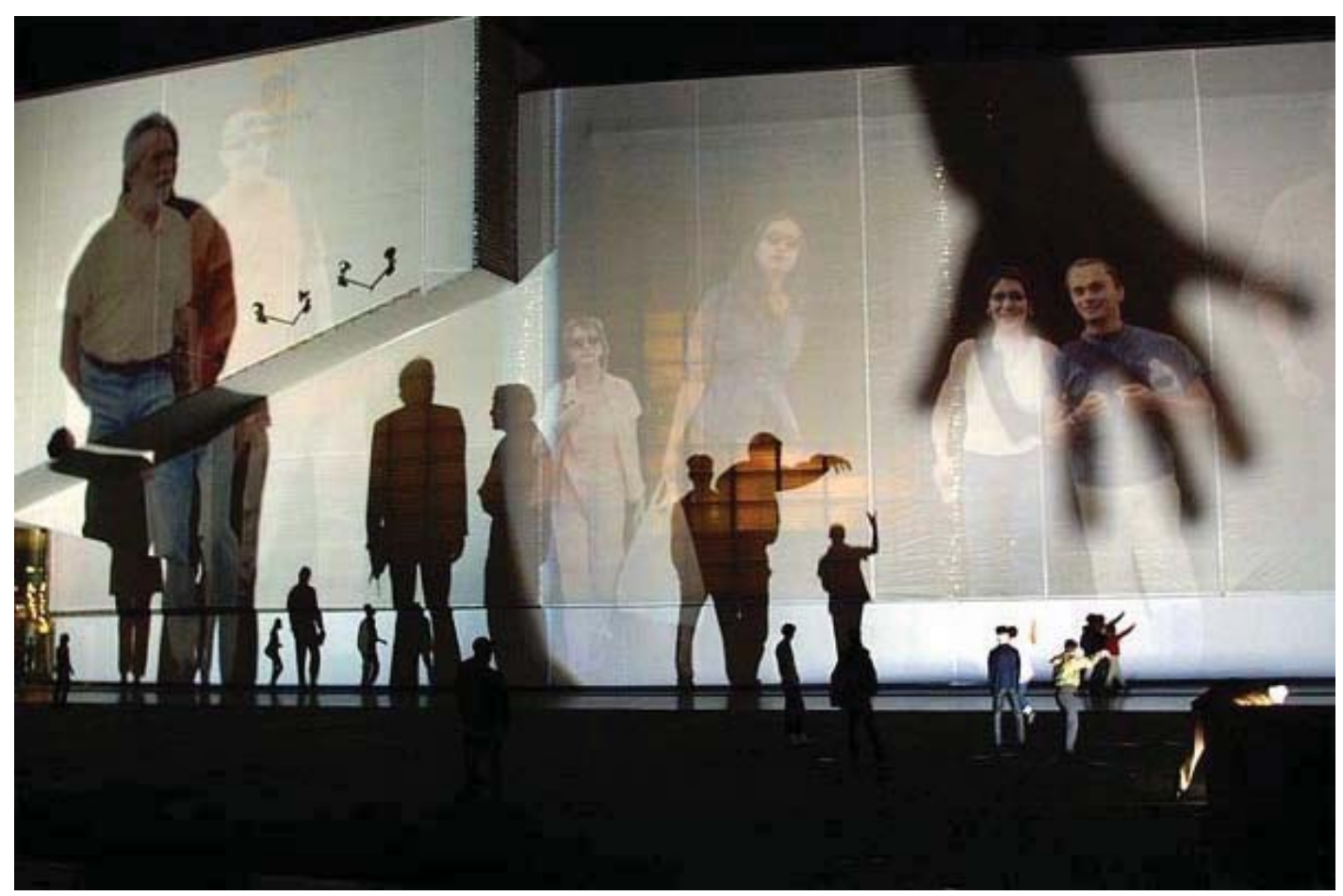

Figure 8: Rafael Lozano-Hemmer, 'Body Movies', 2001, Rotterdam

\section{Conclusion}

Part of Benjamin's argument about the radical impact of cinema in the context of the modern city was that - like architecture - it was consumed in a distracted state. Rather than the focused attention habitually given to the traditional work of art, the film image acted at the margins of conscious perception. In this way it was able to circumvent the habitual defence shield built by each the modern city dweller to protect themselves from the demands of urban life.

Body Movies occupies a similar liminal terrain. Passers-by aren't sure what to make of it; the interface is striking but not immediately comprehensible. Habit is suspended in favour of experimentation. Unexpected conjunctions emerge. In contrast to the paranoia towards strangers that constitutes so much official rhetoric post 9/11, Body Movies celebrates the spontaneous alignments that can make genuine public encounters - in Richard Sennett's terms encounters with strangers - so memorable.

Such tactical interventions into urban space provide a striking comparison to manufactured 'media events', where the media simultaneously desires spontaneity as a way of attracting an audience, but generally occludes the spontaneous by imposing standardised frames in order to minimise the risk that 'nothing happens'. Rather than the usual goal of informational speed and transparency, media technology in Body Movies provides an 'affective' experience which becomes a potential basis for reflexive public interactions.

Many other works are exploring a similar terrain: for example, exploring the way that pedestrian density [or informational density] can produce visual and audiovisual effects. These effects are not just 'messages' but maps of complex social relations. They could become important tools for rethinking the submission of urban space to commodity spectacle and surveillance, and for forging new ways of engaging with others in public. This is increasingly a political undertaking a deep and vital sense. 


\section{About the author}

Scott McQuire is a senior lecturer at the Media \& Communications department of the University of Melbourne. He completed his postgraduate studies on the social effects of camera technologies in the Politics Department at the University of Melbourne. Since then, Scott has written numerous publications and lectured across a variety of disciplines including politics, sociology, cinema studies, art and architecture, as well as media and communication. His current research explores the social effects of media technologies, with particular attention to their impact on the social relations of space and time, and the formation of identity.

\section{http://www.mediacomm.unimelb.edu.au/aboutus/staff/scott.html}

E-mail: mcquire [at] unimelb [dot] edu [dot] au

\section{References}

Benjamin, W. (1996), 'One Way Street' in Selected Writings (Volume 1 19131926) (Marcus Bullock and Michael W. Jennings, eds. trans. Rodney Livingstone and others), Cambridge. MA and London, Belknap Press.

Benjamin, W. (2003) 'Some Motifs in Baudelaire' in Selected Writings (Volume 4 1938-1940) (Howard Eiland and Michael. W. Jennings, eds., trans. E. Jephcott and others), Cambridge. MA and London, Belknap Press.

Berman, M. (1982), All that is Solid Melts into Air: The Experience of Modernity, New York, Simon and Schuster.

Bourriaud, N. (2002) Relational aesthetics (trans. S. Pleasance \& F. Woods), Paris, Les presses du reel.

Broeckmann, A. (2000) 'Expressing connection: relational architecture' in LozanoHemmer, R. (ed.), Vectorial Elevation: Relational Architecture no. 4, Mexico, Mexico City, Conaculta and Ediciones San Jorge, 2000.

Castells, M. (1989) The informational city: information technology, economic restructuring, and the urban-regional process, Oxford, UK and Cambridge, MA., Blackwell.

Clark, T.J. (1999) The Painting of Modern Life: Paris in the art of Manet and his followers, Princeton, Princeton University Press (first published 1984)

Corbusier (1964) The Radiant City: Elements of a Doctrine of Urbanism to be Used as the basis of our Machine-Age Civilization, (trans P. Knight, E. Levieux and D. Coltman), New York, The Orion Press. (first published 1935)

Dayan, D. and Katz, E. (1992) Media events: the live broadcasting of history, Cambridge, MA., Harvard University Press.

Habermas, J. (1989) Structural Transformation of the Public Sphere: An Inquiry into a Category of Bourgeois Society, (trans. T. Burger with the assistance of F. Lawrence), Cambridge, MA, MIT Press. (first published in German in 1962)

Harvey, D. (2003) Paris, Capital of Modernity, New York and London, Routledge. Jacobs, J. (1961) The death and life of great American cities, New York, Random House.

Kasinitz, P. (ed.) (1994) Metropolis: Center and Symbol of Our Times, Macmillan, 
London .

McQuire, S. (2005) 'Immaterial Architectures: urban space and electric light', Space and Culture, 8 (2): 126-140.

Nye, D. (1994) American Technological Sublime, Cambridge, Mass., MIT Press.

Sennett, R. (1977), The Fall of Public Man, New York, Alfred A. Knopf.

Sennett, R. (1994) 'Community Becomes Uncivilized' in Kasinitz, P. (ed.)

Metropolis: Center and Symbol of Our Times, Macmillan, London

Simmel, G. (1997) 'The Metropolis and Mental Life' in Simmel on Culture (eds.

Frisby, D. and Featherstone, M.). London, Sage.

Venturi, R. (1966), Complexity and Contradiction in Architecture, New York, Museum of Modern Art.

Virilio, P. (1991) 'The Overexposed City' in The Lost Dimension (trans. D.

Moshenberg), New York, Semiotexte.

Virilio, P. (1994) The Vision Machine (trans. J. Rose), London, BFI.

Copyright (C)2006, First Monday

Copyright (C2006, Scott McQuire

The politics of public space in the media city by Scott McQuire

First Monday, Special Issue \#4: Urban Screens: Discovering the potential of outdoor screens for urban society (February 2006),

First Monday, Special Issue \#4: Urban Screens: Discovering the potential of outdoor screens for urban society

http://firstmonday.org/htbin/cgiwrap/bin/ojs/index.php/fm/article/viewArticle/1544/1459 
McQuire 
McQuire 
McQuire 
McQuire 
McQuire 
McQuire 


\section{University Library}

\section{- M M I N E R VA A gateway to Melbourne's research publications}

Minerva Access is the Institutional Repository of The University of Melbourne

Author/s:

MCQUIRE, SCOTT

Title:

The politics of public space in the media city

Date:

2006-02

Citation:

McQuire, S. (2006). The politics of public space in the media city. First Monday Special Issue \#4: Urban Screens: Discovering the Potential of Outdoor Screens for Urban Society.

Publication Status:

Published

Persistent Link:

http://hdl.handle.net/11343/34712 